\title{
PREOPERATIVE MANOMETRY FOR THE SELECTION OF OBESE PEOPLE CANDIDATE TO SLEEVE GASTRECTOMY
}

\author{
Manometria pré-operatória para a seleção de obesos candidatos à gastrectomia vertical \\ Antonio Carlos VALEZI' ${ }^{1}$ Fernando Augusto HERBELLA', Jorge MALI-JUNIOR', \\ Mariano de Almeida MENEZES ${ }^{1}$, Mário LIBERATTI ${ }^{1}$, Rafael Onuki SATO ${ }^{1}$
}

From the ${ }^{1}$ Disciplina de Cirurgia do Aparelho Digestivo, Departamento de Cirurgia, Universidade Estadual de Londrina ('Digestive System Surgery, Department of Surgery, State University of Londrina), Londrina, PR, Brazil
ABSTRACT - Background: Sleeve gastrectomy may alter esophageal motility and lower esophageal sphincter pressure. Aim: To detect manometric changings in the esophagus and lower esophageal sphincter before and after sleeve gastrectomy in order to select patients who could develop postoperative esophageal motilitity disorders and lower esophageal sphincter pressure modifications. Methods: Seventy-three patients were selected. All were submitted to manometry before the operation and one year after. The variables analyzed were: resting pressure of the lower esophageal sphincter, contraction wave amplitude, duration of contraction waves, and esophageal peristalsis. Data were compared before and after surgery and to the healthy and non-obese control group. Exclusion criteria were: previous gastric surgery, reflux symptoms or endoscopic findings of reflux or hiatal hernia, diabetes and use of medications that could affect esophageal or lower esophageal sphincter motility. Results: $49 \%$ of the patients presented preoperative manometric alterations: lower esophageal sphincter hypertonia in $47 \%$, lower esophageal sphincter hypotonia in $22 \%$ and increase in contraction wave amplitude in $31 \%$. One year after surgery, manometry was altered in $85 \%$ of patients: lower esophageal sphincter hypertonia in $11 \%$, lower esophageal sphincter hypotonia in $52 \%$, increase in contraction wave amplitude in $27 \%$ and $10 \%$ with alteration in esophageal peristalsis. Comparing the results between the preoperative and postoperative periods, was found statistical significance for the variables of the lower esophageal sphincter, amplitude of contraction waves and peristalsis. Conclusion: Manometry in the preoperative period of sleeve gastrectomy is not an exam to select candidates to this technique.
HEADINGS - Obesity. Manometry. Esophagogastric junction.
RESUMO - Racional: A gastrectomia vertical pode determinar alterações na motilidade esofágica e no esfíncter inferior do esôfago. Objetivo: Estudar as alterações manométricas do esfíncter inferior do esôfago e do esôfago antes e depois da operação a fim de selecionar pacientes que pudessem desenvolver alterações pós-operatórias. Métodos: Setenta e três pacientes foram selecionados. Todos foram submetidos à manometria antes da operação e um ano após. As variáveis analisadas foram: pressão do esfíncter inferior do esôfago, amplitude e duração das ondas de contração e peristaltismo esofágico. Os dados foram comparados entre si antes e depois da operação e também com grupo controle saudável e não obeso. Critérios de exclusão foram: operação gástrica prévia, história de refluxo ou achado endoscópico de esofagite de refluxo ou de hérnia de hiato, diabete e uso de medicamentos que pudessem afetar a motilidade do esôfago ou do esfíncter esofágico inferior. Resultados: $49 \%$ dos pacientes apresentaram alterações no pré-operatório: hipertonia do esfíncter em $47 \%$, hipotonia do esfíncter em $22 \%$ e aumento na amplitude das ondas de contração em $31 \%$. Um ano após, a manometria encontrou-se alterada em $85 \%$ dos pacientes: hipertonia do esfíncter em $11 \%$, hipotonia do esfíncter em $52 \%$, aumento na amplitude das ondas de contração em $27 \%$ e $10 \%$ com alteração no peristaltismo esofágico. Comparando-se os resultados entre o pré e pós-operatório encontrou-se significância estatística para a pressão do esfíncter inferior do esôfago, amplitude das ondas de contração e peristaltismo. Conclusão: A manometria no pré-operatório da gastrectomia vertical não é fator de seleção dos candidatos a essa técnica.
$\mathrm{O}$ besity is associated with an increased incidence of gastroesophageal reflux (GER) ${ }^{9}$. Weight loss determined by bariatric surgery can reduce these symptoms. The improvement depends on the surgical technique employed, for example, the adjustable gastric band, in spite of inducing weight loss, may worsen GER; gastric bypass decreases weight and shows excellent results on the improvement of the GER symptoms ${ }^{21,32}$. Vertical gastrectomy is a good option for weight loss, but transforming the stomach into a cylindrical structure and altering the anatomy of the esophagogastric junction, it may alter the function of the lower esophageal sphincter (LES) and, consequently, some patients submitted to this technique may develop GER ${ }^{5,6,12}$. Several studies have studied the symptoms of GER in the postoperative period of vertical gastrectomy, but few have evaluated the esophagogastric junction ${ }^{3,16}$.

The purpose of this study was to determine the manometric changes of the LES and esophageal body before and after performing vertical gastrectomy compared to healthy volunteers. The hypothesis was that surgical manipulation near the esophagogastric angle during the operation could affect LES function and esophageal motility. 
METHODS

This study was approved by the ethics and research committee of the State University of Londrina. It is a prospective cohort with a consecutive sample of the convenience of 87 obese subjects submitted to vertical gastrectomy from April 2012 to March 2014. The surgical indication obeyed the international criteria for performing bariatric surgery. Exclusion criteria were: previous gastric surgery, history of GERD or endoscopic finding of reflux esophagitis or hiatal hernia, diabetes and use of medications that could affect esophageal or lower esophageal sphincter motility. Patients who had postoperative complications that required surgical or endoscopic treatment, those who did not complete the study or those who refused to participate in the study were excluded from the analysis, so the data refer to 73 patients: 18 men and 55 women, with a mean age of 40.2 years (19-61) and mean body mass index (BMI) of $41.1 \mathrm{~kg} / \mathrm{m}^{2}(35-46)$.

The patients selected for thestudywere submitted to manometry before and one year after surgery. The variables analyzed were resting pressure of the LES in $\mathrm{mmHg}$ (considering normal values between $10-35 \mathrm{mmHg}$ ), contraction wave amplitude in $\mathrm{mmHg}$ (normal values of $64-154 \mathrm{mmHg}$ ), duration of contraction waves in seconds and esophageal peristalsis. The data were compared before and after the operation and the findings of the healthy and non-obese control group, composed of 10 volunteers, were also compared. The control group did not present gastrointestinal symptoms, previous abdominal operations and did not use any type of medication that could interfere in the esophageal motility or the LES pressure. All patients were operated by the same surgeon and the manometry performed by a single examiner. All obese participants in the study signed informed consent for the study.

\section{Esophageal manometry}

The test was performed with an eight-channel, water-infused device after an $8 \mathrm{~h}$ fast. The manometric data were obtained through 10 swallows of $5 \mathrm{ml}$ of water with interval of $5 \mathrm{~min}$. Synetics ${ }^{R}$ software, USA, was used for data interpretation and analysis. Ten days before the study, drugs that could interfere with esophageal motility and proton pump inhibitors were discontinued. There were no complications during the exams.

\section{Surgical technique}

Vertical gastrectomy was performed with the surgeon between the patient's legs. Initially, the vessels were released from the great gastric curvature from $4 \mathrm{~cm}$ of the pylorus until the gastric fundus was completely released and the diaphragmatic pillarwas seen. After this surgical time a $32 \mathrm{~F}$ oro-gastric probe was introduced to the duodenum. The stomach was sectioned using a laparoscopic stapler along the gauge probe, starting $4 \mathrm{~cm}$ from the pylorus and continuing cranially to the esophagogastric angle. The last stapling was done $1 \mathrm{~cm}$ laterally to the esophagus. After removal of the stomach from the abdominal cavity, invaginating continuous suture was made with absorbable yarn of the staple line and methylene blue test was done. There was no intraoperative complication or need for conversion to laparotomy.

\section{Statistical analysis}

The variables were analyzed using non-parametric tests, Wilcoxon test for paired samples and Mann-Whitney for simple samples. Statistical significance was considered when $p$ was less than or equal to 0.05 .

\section{RESULTS}

Of the 73 patients, 36 (49\%) presented manometric changes in the preoperative period. The alterations found in this group were: LES hypertonia in 17 (47\%), eight LES hypotonia (22\%) and 11 with an increase in contraction wave amplitude
(31\%). One year after the operation, manometry was altered in 62 patients (85\%). The findings in this group were: LES hypertonia in seven (11\%), 32 LES hypotonia (52\%), 17 with an increase in contraction waves amplitude (27\%) and six (10\%) with alterations in esophageal peristalsis The control group did not present manometric alterations (Table 1).

TABLE 1 - Manometric findings $(n=73)$

\begin{tabular}{|l|c|c|c|}
\hline \multicolumn{1}{|c}{ Findings } & Pre & Post & Control \\
\hline LES hypertonia & 17 & 7 & - \\
\hline LES hypotonia & 8 & 32 & - \\
\hline High contratility & 11 & 17 & - \\
\hline Disperistalsis & - & 6 & - \\
\hline
\end{tabular}

LES= lower esophageal sphincter; pre=preoperative; post=postoperative

Lower esophageal sphincter pressure before and after the operation was $26.59 .1 \mathrm{mmHg}$ and $12.6 \pm 8.7 \mathrm{mmHg}$, respectively. The amplitude of the contraction waves was $133.1 \pm 38.7 \mathrm{mmHg}$ in the preoperative period and in the postoperative period was $146.5 \pm 37.7 \mathrm{mmHg}$. The duration of pre and postoperative contraction waves was $4.2 \pm 1.1 \mathrm{~s}$ and $5.7 \pm 1.1 \mathrm{~s}$, respectively. Normal peristalsis occurred in $100 \%$ of the patients before the operation and in $90 \%$ after (Table 2).

\section{TABLE 2 - Manometric changes}

\begin{tabular}{|c|c|c|c|}
\hline & Pre & Post & Control \\
\hline LES pressure $(\mathrm{mmHg})$ & $26.5 \pm 9.1$ & $12.6 \pm 8.7$ & $17.8 \pm 4.9$ \\
\hline Wave amplitude $(\mathrm{mmHg})$ & $133.1 \pm 38.7$ & $146.5 \pm 37.7$ & $100.3 \pm 30.1$ \\
\hline Wave duration $(\mathrm{mmHg})$ & $4.2 \pm 1.1$ & $5.7 \pm 1.1$ & $5.0 \pm 0.9$ \\
\hline Normal peristalsis $(\%)$ & 100 & 90 & 100
\end{tabular}

LES= lower esophageal sphincter; pre=preoperative; post=postoperative

Comparing the results of the preoperative period with the control group, statistical significance was not found for the variables analyzed. When comparing the postoperative results with the control, there was a significant difference in the LES pressure and the amplitude of the contraction waves. Comparing the results between the preoperative and postoperative periods, statistical significance was found for the variables LES pressure, amplitude of contraction waves and peristalsis (Table 3).

TABLE 3 - Statistical analysis of pre and postoperative findings

\begin{tabular}{|c|c|c|c|c|c|c|c|}
\hline & \multicolumn{3}{c}{ Medians } & \multicolumn{4}{c}{ p } \\
\cline { 2 - 8 } & \multicolumn{1}{c}{ Pre } & Post & Control & $\begin{array}{c}\text { Pre } x \\
\text { Post }\end{array}$ & $\begin{array}{c}\text { Pre } \mathrm{x} \\
\text { Control }\end{array}$ & $\begin{array}{c}\text { Post } \mathrm{x} \\
\text { Control }\end{array}$ \\
\hline $\begin{array}{c}\text { LES pressure } \\
\text { (mmHg) }\end{array}$ & 26.5 & 12.6 & 17.8 & 0.0001 & 0.2657 & 0.0001 \\
\hline $\begin{array}{c}\text { Wave amplitude } \\
\text { (mmHg) }\end{array}$ & 133 & 146.5 & 100.3 & 0.0001 & 0.5789 & 0.0001 \\
\hline $\begin{array}{c}\text { Wave duration } \\
\text { (mmHg) }\end{array}$ & 4.2 & 5.7 & 5.0 & 0.4387 & 0.6769 & 0.8243 \\
\hline $\begin{array}{c}\text { Normal peristalsis } \\
\text { (\%) }\end{array}$ & 100 & 90 & 100 & 0.0001 & 0.6239 & 0.0001 \\
\hline
\end{tabular}

LES= lower esophageal sphincter; pre=preoperative; post=postoperative

\section{DISCUSSION}

In this research we studied patients without GER because the objective was to evaluate the effects of vertical gastrectomy on esophageal motility and lower esophageal sphincter function. The absence of GER was defined by the absence of symptoms and normal endoscopic examination. The lack of esophageal phmetry in this population may be a bias in this research, since GER may be present in asymptomatic patients ${ }^{7}$.

A control group was constituted in this research, due to the fact that manometric changes in the esophagus can occur in non-obese asymptomatic individuals ${ }^{13,14,24,25}$.

Manometry is an important tool for the study of LES and 
esophageal body function². High-definition manometry is a better examination in this respect, but it is not available in our service, so conventional manometry was used ${ }^{11}$. The resting pressure of the LES was used because it represents its isolated pressure, without the interference of the diaphragmatic pillars².

In the studied population, we found preoperative manometric changes in $49 \%$ of the obese, with an increase in the amplitude of the contraction waves. A previous study by our team ${ }^{30}$ identified changes in manometry in $45.6 \%$ of the obese studied and the amplitude of the contraction waves was also predominant.

Several publications have shown that vertical gastrectomy is an effective method for weight loss and improvement of comorbidities ${ }^{1,17,31}$; however, its effect on the possibility of GER is controversial ${ }^{18,20,26,27}$. Mechanisms that may lead to GER after vertical gastrectomy include increased intragastric pressure, modification of the gastroesophageal junction and alteration in the mechanics of LES $^{19,23}$.

Manometric studies after vertical gastrectomy showed a significant decrease in LES pressure ${ }^{4,8,10}$. In this study, there was alteration of the esophageal function, with an increase in the contraction wave amplitude and worsening of the peristalsis after the operation, and there was also a significant decrease in the LES pressure.

The worsening of esophageal motor function is most likely due to the increase in the pressure of the interior of the stomach after vertical gastrectomy and the decrease of the pressure of the LES possibly occurs due to the injury of the muscular fibers of the esophagogastric transition ${ }^{28,29}$.

Data on manometric changes of the LES are controversial. Braghetto et al. ${ }^{3}$ observed a decrease in the resting pressure of the LES six months after vertical gastrectomy, probably due to the lesion of the arched fibers of the cardia. In this study, we found similar data, with a significant decrease in LES pressure.

Kleidi et al. ${ }^{15}$ assessed asymptomatic patients regarding GER and with normal LES pressure in the preoperative period and found an increase in the extent of the LES; however, they observed a decrease in contraction of the distal esophagus that could interfere with esophageal whitening, determining GER independently of LES pressure. Petersen et al. ${ }^{22}$ found an increase in LES pressure shortly after the operation, and that this finding was not dependent on weight loss, but on placement of the stapler further away from the esophagus to avoid lesion of the sphincter fibers.

Gastroesophageal reflux after vertical gastrectomy can vary from 2.8 to $13 \% \%^{4,28,29}$. Manometry should be routine preoperative examination in obese candidates for this surgical technique, because if the patients present low pressure of the LES, vertical gastrectomy should not be performed ${ }^{32}$.

This is also the opinion of the authors of this study and if we were able to select preoperatively those patients who could develop postoperative esophageal motor complications, the results would surely be better. This is why this study was carried out. We found alterations in the postoperative period of the vertical gastrectomy, but they were not correlated with the manometric findings in the preoperative period.

\section{CONCLUSION}

It can not be concluded that the manometry in the preoperative period of vertical gastrectomy is a selection factor for the candidates for this operative technique.

\section{REFERENCES}

1. Arman GA, Himpens J, Dhaenens J etal. Long-term (11+years) outcomes inweight, patientsatisfaction, comorbidities, and gastroesophageal reflux treatment after laparoscopic sleeve gastrectomy. Surg Obes Relat Dis. 2016;19:1550-9.

2. Bowers SP. Esophageal motility disorders. Surg Clin North Am. 2015;95:467-82.
3. Braghetto I, Lanzarini E, Korn W et al. Manometric changes of the lower esophageal sphincter after sleeve gastrectomy in obese patients. Obes Surg. 2010;20:357-62.

4. BurgerhartJS1,SchotborghCA,SchoonEJetalEffectofsleevegastrectomy on gastroesophageal reflux. Obes Surg. 2014;24:1436-41.

5. Carter PR, Le Blanc KA, Hausmann MG et al. Association between gastroesophageal reflux disease and laparoscopic sleeve gastrectomy. Surg Obes Relat Dis.2011;7:569-72.

6. Daes J, Jimenez ME, Said N et al. Laparoscopic sleeve gastrectomy: symptoms of gastroesophageal reflux can be reduced by changes in surgical technique. Obes Surg. 2012; 22:1874-9.

7. Delattre JF, Avisse C, Marcus $C$ et al. Functional anatomy of the gastroesophageal junction. Surg Clin North Am. 2000;80:241-60.

8. DuPree CE, Blair K, Steele SRI et al. Laparoscopic sleeve gastrectomy in patients with preexisting gastroesophageal reflux disease: a national analysis. JAMA Surg. 2014;149:328-34.

9. El-Serag $\mathrm{H}$. The association between obesity and GERD: a review of the epidemiological evidence. Dig Dis Sci. 2008;53:2307-12.

10. Gorodner V, Buxhoeveden R, Clemente G et al. Does laparoscopic sleeve gastrectomy have any influence on gastroesophageal reflux disease? Preliminary results. Surg Endosc. $2015 ; 29: 1760-8$.

11. Herbella FA, Patti MG. Can high resolution manometry parameters for achalasia be obtained by conventional manometry? World J Gastrointest Pathophysiol. 2015;15:58-61.

12. Howard DD, Caban AM, Cendam Jc et al. Gastroesophageal reflux after sleeve gastrectomy in morbidly obese patients. Surg Obes Relat Dis.2011;7:709-13.

13. JC, Lima GR, Silva DH et al. Cilinical, endoscopic and manometric features of the primary motor disorders of the esophagus. Arq Bras Cir Dig. 2015:28:32-5.

14. Jones R, LikerHR, DucrottéP. Relationshipbetweensymptoms, subjective well-being and medication use in gastro-oesophageal reflux disease. Int J Clin Pract. 2007;61:1301-7.

15. Kleidi E, Theodorou D, Albanopoulos K et al. The effect of laparoscopic sleeve gastrectomy on the antireflux mechanism: can it be minimized? Surg Endosc. 2012;22:360-6.

16. Kleidi E, Theodorou D, Albanopoulos K et al. The effect of laparoscopic sleeve gastrectomy on the antireflux mechanism: can it be minimized? Surg Endosc. 2013;27:4625-30.

17. Maciejewski ML, Arterburn DE, Van Scoyoc L et al. Bariatric Surgery and Long-term Durability of Weight Loss. JAMA Surg. 2016;151:1046-55.

18. Melissas J, Braghetto I, Molina JC et al. Gastroesophageal Reflux Disease and Sleeve Gastrectomy. Obes Surg. 2015 Dec;25(12):2430-5.

19. Mion F, Tolone S, Garros A et al. High-resolution Impedance Manometry after Sleeve Gastrectomy: Increased Intragastric Pressure and Reflux are Frequent Events. Obes Surg. 2016;26:2449-56.

20. Oor JE, Roks DJ, Ünlü Ç et al. Laparoscopic sleeve gastrectomy and gastroesophageal reflux disease: a systematic review and meta-analysis. Am J Surg. 2016;211:250-67.

21. Padwal $R$, Klarenbach $S$, Wiebe $N$ et al. Bariatric surgery: a systematic review and network meta-analysis of randomized trials. Obes Rev. 2011:12:602-21.

22. Petersen WV, Meile T, Kuper MA et al. Functional importance of laparoscopic sleeve gastrectomy for the lower esophageal sphincter in patients with morbid obesity. Obes Surg. 2012;22:360-6.

23. Rebecchi F, Allaix ME, Giaccone C et al. Gastroesophageal reflux disease and laparoscopic sleeve gastrectomy: a physiopathologic evaluation. Ann Surg. 2014;260:909-14.

24. Rezende DT, Herbella FA, Silva LC et al. Upper esophageal sphincter resting pressure varies during esophageal manometry. Arq Bras Cir Dig. 2014:27:182-3.

25. Ribeiro JB, Diógenes EC, Bezerra PC et al. Lower esophageal sphincter pressure measurement under standardized inspiratory maneuvers. Arq Bras Cir Dig. 2015:28:174-7.

26. Sheppard CE, Sadowski DC, de Gara CJ et al. Rates of reflux before and after laparoscopic sleeve gastrectomy for severe obesity. Obes Surg. 2015 May;25(5):763-8.

27. StenardF, lannelliALaparoscopicsleevegastrectomyandgastroesophageal reflux. World J Gastroenterol. 2015 Sep 28;21(36):10348-57.

28. TaiCM1, HuangCK. Increaseingastroesophageal refluxdiseasesymptoms and erosive esophagitis 1year after laparoscopic sleeve gastrectomy among obese adults. Surg Endosc. 2013;27:3022-4.

29. Thereaux J, Barsamian C, Bretault $\mathrm{M}$ et al. $\mathrm{pH}$ monitoring of gastrooesophageal reflux before and after laparoscopic sleeve gastrectomy. Br J Surg. 2016;103:399-40.

30. Valezi AC, Herbella FAM, Mali Jr J et al. Esophageal motility after laparoscopic Roux-en-Y gastric bypass: the manometry be preoperative examination routine? Obes Surg. 2012;22:1050-4.

31. Vuolo G, Voglino C, Tirone A et al. Is sleeve gastrectomy a therapeutic procedure for all obese patients? Int J Surg. 2016;30:48-55.

32. Zhang N, Maffei A, Cerabona T et al. Reduction in obesity-related comorbidities: is gastric bypass better than sleeve gastrectomy? Surg Endosc. 2013;27:1273-80. 